Copyright: Journal of Medical Ethics

Article can be accessed at http://jme.bmj.com/content/38/7/431.long.

\title{
JORIS GIELEN
}

MAHĀTMĀ GANDHI's VIEW ON EUTHANASIA AND ASSISTED SUICIDE

\begin{abstract}
To many in India and elsewhere, the life and thoughts of Mohandas Karamchand Gandhi are a source of inspiration. The idea of non-violence was pivotal in his thinking. In this context, Gandhi reflected upon the possibility of what is now called 'euthanasia' and 'assisted suicide'. So far, his views on these practices have not been properly studied. In his reflections on euthanasia and assisted suicide, Gandhi shows himself to be a contextually flexible thinker. In spite of being a staunch defender of non-violence, Gandhi was aware that violence may sometimes be unavoidable. Under certain conditions, killing a living being could even be an expression of non-violence. He argued that in a few rare cases it may be better to kill people who are suffering unbearably at the end of life. In this way, he seems to support euthanasia and assisted suicide. Yet, Gandhi also thought that as long as care can be extended to a dying patient, his or her suffering could be relieved. Since in most cases relief was thus possible, euthanasia and assisted suicide were in fact redundant. By stressing the importance of care and nursing as an alternative to euthanasia and assisted suicide, Gandhi unconsciously made himself an early advocate of palliative care in India. This observation could be used to strengthen and promote the further development of palliative care in India.
\end{abstract}




\section{MAHĀTMĀ GANDHI's VIEW ON EUTHANASIA AND AsSISTED SUICIDE}

\section{Introduction}

Mohandas Karamchand Gandhi (1869-1947), also called Mahātmā Gandhi, is without doubt one of the most well-known figures in Indian history. Even more than 60 years after his untimely death, his life and ideas are still a source of inspiration for people worldwide who are denouncing wrongs in society and attempt to rectify these. Gandhi's thoughts and life have a strong appeal for many Indians and people of Indian origin living outside India. In 2011, the social activist Anna Hazare (born in 1937) made international headlines with his massive mobilisation of the Indian middle class. Using Gandhian imagery and methods, he campaigned among others for a strong Lokpal Bill, which was intended to end corruption in India. Social protests that draw inspiration from Gandhi have not remained restricted to India. For instance in 2008, in New Orleans a group of over 100 Indians who were the victims of human trafficking protested against their plight by resorting to satyāgraha, Gandhi's nonviolent method. [1]

To those not acquainted with Gandhi's thoughts, it may seem strange that his ideas appeal in contexts that are so markedly different from the context of the Indian struggle for independence in which they originated. Yet, he was a very versatile thinker. In his view, non-violence was a way of life and not just a means to obtain independence for India. In his letters, books and articles, he attempted to show how people could practice non-violence in their daily lives. In these writings, we see how Gandhi tried to deal with problems that were or could be faced by those who wanted to follow this non-violent way of life. He was very much aware of the fact that in certain cases other values could collide with the idea of nonviolence. He reflected upon cases in which such ethical conflict could occur, and attempted to formulate guidance to overcome such dilemmas. In this way, Gandhi was confronted with the problem of unbearable suffering at the end of life. Gandhi and his correspondents raised the question whether ending or helping to end the life of an animal or human being whose suffering is considered unbearable could be acceptable. In this sense, Gandhi pondered on the issues of what we now call 'euthanasia' and 'assisted suicide'. Euthanasia is 'the intentional administration of lethal drugs in order to painlessly terminate the life of a patient suffering from an incurable condition deemed unbearable'. Assisted suicide means 'intentionally assisting a patient, at this patient's request, to terminate his or her life'. [2-4]

Given the fact that Gandhi was such an influential Hindu thinker, it is surprising that authors who have systematically analysed the Hindu attitude to euthanasia and assisted suicide have given no or only cursory attention to his arguments. [5-8] Moreover, Gandhi's reflections are of relevance to our current context in which euthanasia and assisted suicide have become much-debated ethical topics. Gandhi has provided a critical Indian response to these issues. He shows how a person who is steeped in non-violence can react to requests or the desire to end the life of a suffering living being. To better understand Gandhi's view on euthanasia and assisted suicide, first, his dynamic interpretation of non-violence, or ahims $\bar{a}$, will be discussed in this article. Next, an assessment of the way in which euthanasia and assisted suicide fit into this framework and under which conditions they can be permitted is presented. Then, it will be shown how Gandhi included reflections on care for the terminally ill in his arguments regarding the (im)permissibility of euthanasia and assisted suicide. Finally, the contemporary relevance of these observations are also illustrated. 


\section{Gandhi's Dynamic Interpretation of Non-violence}

Ahimsā is a central idea in Gandhi's thought. Ahimsā could be translated as 'not-injuring', 'not-harming' or, more generally, 'non-violence'. For Gandhi, non-violence or ahimsā has a broader meaning than just a prohibition to kill or an exhortation to refrain from violence. Ahimsā implies abstaining from 'causing pain to or killing any life out of anger or from a selfish purpose, or with the intention of injuring it' (Collected Works of Mahatma Gandhi [CW] [9] vol. 31, p. 545). The principle of ahims $\bar{a}$ is not restricted to acts. It also pertains to words and thoughts. In order to determine whether an act, statement or thought violates the principle of ahimsā the true intention behind it has to be assessed. Violence occurs whenever there is an intention to harm.

In Gandhi's view, anyone who wishes to reach a certain goal should reflect upon ahims $\bar{a}$. It is a central principle (e.g. CW vol. 18, p. 133; Selections from Gandhi [SG] [10] p. 145). Ahimsā not only entails an encompassing prohibition to harm. In a positive sense, it is an attitude that demands compassion for all living things. Ahimsā becomes then an expression of love. For Gandhi, this love was rooted in a profound belief and trust in the God of love. He strongly believed in the existence of a personal loving God and reasoned that only those who believe in the God of love can love the whole of humanity, and, in this way, fully practice ahimsā (CW vol 49, pp 429-32; vol 63, p 262; SG, pp 150-2). In this sense, ahimsā was a religious principle to him.

However, being a practical thinker, Gandhi was aware of the limitations of nonviolence. According to him, the ideals of ahimsā could never be completely realised because in day-to-day lives small or big instances of violence occur regularly. Sometimes, violence and even killing could be unavoidable. In this context, he gave the example of killing insects and microbes for health reasons. Also a rabid dog could be killed in order to prevent such a dog from biting other dogs or infecting humans. Gandhi considered the killing of the dog a sin; yet, not killing the dog would be a graver sin, as other lives would be endangered. Gandhi constructed a similar argument regarding a man threatening to kill others. Killing such a man could be a necessity. Also self-defence and fighting to protect possessions or honour could be justified ( $\mathrm{CW}$ vol 18, p 132; vol 21, pp 321-2; vol 31, pp 486-9, 544; vol 61, pp 264-7; SG, pp 155-6).

Gandhi was of the opinion that in certain cases violence could be used to protect one's own life or that of others. However, even in such cases people should not resort to violence lightly, and violence could only be used after long critical reflection showed that no other solutions are possible (CW vol 31, pp 544-7). Gandhi realised that this kind of criteria are hard to objectively verify in concrete cases. Although Gandhi thought that violence could sometimes be 'unavoidable', he also argued that 'unavoidable violence' cannot be unambiguously defined '[f]or it changes with time, place and person'. According to him, the permissibility of violence depends on the concrete context and it is impossible to formulate absolute rules (CW vol 32, pp 72-3, 381).

Gandhi's argument did not stop with pointing out that violence could sometimes be permissible or unavoidable. He even went further and stated that violence and killing could in some cases be an expression of a life focussed on ahimsā. In this context, Gandhi's reflections are connected with the practices of euthanasia and assisted suicide.

\section{Euthanasia and Assisted Suicide as Non-Violence}

Gandhi argued that no violence or ahimsā is committed when a life is ended, when this is judged to be better for the living being concerned. In this regard, he referred to cases of 
extreme uncontrollable suffering. In such instances, taking a life could be seen as an act of compassion. For Gandhi, this applied to both animals and human beings. He argued, for instance, that killing a rabid dog could be justified if the dog is killed out of compassion to prevent it from dying a slow death. From here, he continued that if there would be no possibility to relieve the suffering of a child with rabies, it should also be killed (CW vol 32, $\mathrm{p}$ 42). In Gandhi's cultural and historical context, this was a rather bold reasoning. For many, over the years Gandhi had become non-violence personified. Many were shocked to learn that he, albeit under very specific conditions, extenuated the worst form of violence: killing a living being and even a human.

It is therefore not surprising that protests arose when the news spread that Gandhi had had an ailing calf killed in his ashram in Ahmedabad in 1928. The animal had been crippled and was visibly in great pain. When it became clear that nursing the calf did not bring sufficient relief, the animal was put to death with a lethal injection (CW vol 37, pp 310-11). In Gandhi's opinion, the killing of the calf was justified because it was an expression of ahimsā. It was not an act of violence. In his responses to the controversy surrounding the death of the calf, and in his answers to similar problems and cases, essentially three criteria can be distinguished that had to be fulfilled before killing a living being could be acceptable. These criteria are the absence of self-interest, the occurrence of uncontrollable suffering at the end of life and if the case concerns a human person, consent of the patient if possible. Thus, first, a decision to kill a living being had to be based on 'a view to its spiritual or physical benefit from a pure, selfless intent'. Selfish motives made any act of killing inadmissible (CW vol 37, p 313). According to Gandhi, the killing of the calf was permitted as there was no 'self-interest' involved in the decision to kill (CW vol 37, pp 310-11). The criterion could similarly be applied to human beings.

In December 1926, Gandhi commented on the reported case of an actress in Paris who had shot her life partner, after he had implored her to do so as he was terminally ill and suffering excruciating pain. Gandhi argued that this kind of killing may in fact not be violence if it is done with the right intentions. He added, however, that it was not up to him to be a judge in this case. In his view, only God is capable of rightly judging human intentions (CW vol 32, pp 477-8).

Examples of selfish motives which would make any killing of a suffering living being unacceptable and which were mentioned in Gandhi's writings are financial considerations and the unwillingness to care for the dying living being. In one of the letters received by Gandhi in 1928, a father asked for guidance regarding his 4-month-old child. The child had contracted some disease for which no effective cure seemed available and was visibly suffering. The father asked Gandhi what he should do, adding he had financial problems and indirectly suggesting it might be better to kill the child. Gandhi vehemently opposed this last idea. He suspected that the father was not entirely free of self-interest in his suggestion that killing the child would be the better solution. The father had mentioned he had huge debts and a large family to feed. Gandhi thought this circumstance had stimulated the father to give up on his youngest child. He was also under the impression the father no longer wanted to take the effort to nurse the baby. For Gandhi, such circumstances could never warrant the taking of a life (CW vol 38, pp 66-7).

The second criterion under which killing a living being could be acceptable was the occurrence of uncontrollable suffering at the end of life. Just as the calf in the ashram, a human being who is suffering unbearably and uncontrollably could be killed, provided no help whatsoever could be offered ( $\mathrm{CW}$ vol 37, pp 310-11). Moreover, a person or animal could only be killed if the illness that causes the suffering is incurable and the patient is in the terminal stage of the disease ( $\mathrm{CW}$ vol 37, $\mathrm{p} \mathrm{410).} \mathrm{Gandhi} \mathrm{compared} \mathrm{the} \mathrm{killing} \mathrm{of} \mathrm{a}$ suffering patient with the work of a surgeon. The latter removes parts of the body that are 
in pain or diseased with surgical tools. In the same way, it may sometimes be necessary to remove a body in pain from the soul. In both cases, Gandhi argued, the goal is to relieve the soul from pain (CW vol 37, p 311-12).

The third criterion was consent of the patient if he or she is able to give informed consent. Killing persons who are still capable of expressing their wishes without their permission could never be allowed (CW vol 37, p 410). A conscious patient can decide to kill himself. Gandhi considered it acceptable for a person suffering from an incurable disease to commit suicide provided 'he cannot perform any service whatsoever and lives only as a result of the ministrations of others' (CW vol 50, p 13).

\section{Care for the Terminally Ill}

Although Gandhi could be seen as open to the theoretical possibility of euthanasia and assisted suicide, eventually he would conclude that in the case of suffering terminal patients euthanasia and assisted suicide are not the best solutions, and generally are not permissible. Especially the criterion of the absence of self-interest seriously limited their scope of application. This criterion implied that unwillingness to provide care could never be a reason for euthanasia or assisted suicide. It was everyone's duty to care for the dying. Gandhi argued that dogs and cows that are in terrible agony can be put to death. Yet, for human beings who are in pain in general, other solutions are possible to relieve the pain. Gandhi said that 'as a rule we have always means at our disposal to help them' (CW vol 32, $p$ 42 ; vol 37, p 311). In this way, the condition of human beings was very different from that of animals. Gandhi wrote: '[W]e do not always despair of the life of a person when he is reduced to a comatose state and even when he is past all hope he is not necessarily past all help. More often than not it is possible and practicable to render service to a human patient till the very end' (CW vol 37, p 410). Before any patient could be killed, it had to be ascertained that absolutely nothing could be done for him or her. Gandhi opined that almost always something could still be done. Even a comatose patient could still be cared for. According to him, there were hardly any cases in which care was impossible or meaningless.

One of such case was that of a soldier lethally wounded on the battlefield. Killing him could be justified if it was certain that the required medical care was beyond reach. In Gandhi's view, it would be better to kill such a soldier rather than let him die without care (CW vol 32, p 478). Yet, this case of a person who is beyond help was seen as extreme and rare. A proper response to suffering could hardly ever be killing the patient. Care was a more suitable reaction. Gandhi's advice in concrete cases illustrates this. In the abovementioned case of the ill 4-month-old child, Gandhi pointed out that the father should not attempt to evade his duty to care for the baby and nurse it. He explained, "[ $t$ ] here would be no warrant for taking the life of the baby even if all the doctors in the world were to pronounce the case hopeless because it would always be possible for its father to nurse it.' Killing the baby would only be allowed 'when every possible avenue of service however small is closed' (CW vol 38, pp 66-7).

Another man wrote in a letter to Gandhi about his 20-year-old sister who had been suffering from paralytic attacks. Various treatments had failed to be effective. She had been considering suicide and had asked her brother whether he would allow her to kill herself. Finally, she decided against committing suicide because her suffering would allow her to purify her karma. Karma is related to the belief that every deed done by a living being will have a consequence either in the present life or in a future life. Karma is the combined result of a person's actions and their consequences. From that perspective, suffering could 
be seen as an opportunity to atone for some of the bad karma collected in the past. By committing suicide and ending her life prematurely, the young woman thought she would lose this opportunity. Gandhi, however, admonished her for considering karma as such a mechanical principle. According to him 'the law [of karma] is not a dead, rigid, inert thing, but it is an ever-living, ever growing mighty force'. Gandhi suspected that her desire to commit suicide was rather based on the fear that she would be a nuisance to those who had to care for her daily. He wrote she should not have this kind of feeling, as it was simply the duty of those around her to care for her. He concluded, 'What she considered was an inconvenience to her nurses was a privilege, or should be, in the latter's estimation. And if she desired death, the nurses could not comply with her desire, for that compliance would be tantamount to shirking of an obvious duty' (CW vol 38, pp 108-9).

Gandhi thought that most patients who originally wanted to die would eventually be pleased when they received proper care. Therefore, he considered it very important to try to relieve a patient's suffering by caring and nursing before giving in to a request for euthanasia or assisted suicide. While reflecting on the case of the Parisian actress who had killed her terminally ill lover, Gandhi commented that people who are in great pain, may often wish to die and ask to be killed. Yet, when the pain subsides, they may be glad their request was not granted. Gandhi concluded: 'There are many cases in which a man may for the moment, being overwhelmed with pain, desire to be killed rather than live in agony. But he would be most grateful upon recovery to know that his wish was not complied with.' A mere wish to die expressed by a patient would never be sufficient ground to effectively proceed to kill him or her (CW vol 32, $\mathrm{p} \mathrm{478).}$

From this, it becomes clear that for Gandhi euthanasia and assisted suicide almost never were real options. He, on the contrary, stressed the necessity of care for patients in pain and distress who wanted to die. For him, care for the patient was the proper response to requests for euthanasia and assisted suicide. From this perspective, Gandhi's conclusions resemble the traditional palliative care argument that most euthanasia requests disappear as soon as a patient receives good palliative care, and that, therefore, euthanasia or assisted suicide are redundant. [11] Obviously, the care Gandhi could imagine for terminally ill suffering patients differs to a great extent from what we now know as palliative care. Gandhi had written his reflections on euthanasia and assisted suicide in the 1920s and early 1930s. The modern palliative care movement took off only in the second half of the 20th century, and St Christopher's Hospice, a landmark in the development of palliative care, was founded in London by Cicely Saunders in 1967. [12, 13] Yet, from Gandhi's writings we can surmise that had he been alive today, he would undoubtedly have supported most of the essential principles of palliative care. His call to care for patients instead of administering euthanasia or assisting their suicide, and to never give up caring, points to that direction. His conviction that still 'something' can be done even when curative treatment fails, resembles the idea of holistic care envisioned by palliative care.

Palliative care was introduced in India in the second half of the 1980s. Since then, palliative care programmes have been developed in different parts of India. Yet, coverage of palliative care in India remains a huge problem. According to estimates, $<3 \%$ of those in need of palliative care receive it. [14] At present, palliative care services are functioning in just over half of the Indian states. [15] In most of these states, the services are concentrated in the large cities, and people living in rural areas do not have access to palliative care. Lack of resources and funding hamper the further development and expansion of palliative care programmes. Concrete delivery of palliative care is often also impeded by the absence of awareness of palliative care among the general public and medical professionals. [14, 16-19] In order to further develop palliative care in India there is a need for more support from the general public, medical professionals and the Indian central and state governments. The 
fact that an important inspirational figure like Gandhi formulated ideas that support the underlying principles of palliative care could possibly be used to create awareness about the need and importance of palliative care. Gandhian ideas could be useful in trying to gain support or collect funds for palliative care initiatives in India. When people realise that Gandhi, who is known as the father of the Indian nation, was possibly an early advocate of palliative care in India, they may be more willing to learn about palliative care, donate to palliative care services, work as a volunteer in palliative care programmes or exert political influence to stimulate the development of palliative care policies at the state or national level.

\section{Conclusion}

Non-violence played a central role in Gandhi's thinking. For him, non-violence was an important religious principle. Yet, being a practical contextual thinker, Gandhi was aware that absolute non-violence may actually not be practicable. Moreover, being aware of the complexity and contextual nature of non-violence he realised that killing could sometimes also be motivated by non-violent intentions and therefore need not always be seen as violence. Gandhi's conclusions were prompted by concrete problems to which he attempted to formulate answers by applying the principle of ahimsā in a flexible and open manner. Although ahimsā was a religious principle to him, he refused to stick to one narrow and rigid interpretation of it that would actually have been unfeasible in real life. He also dealt with religious concepts such as karma in an open and flexible manner.

According to Gandhi, sometimes violence could be unavoidable. There were even cases in which killing could be an expression of non-violence. In this way, euthanasia and assisted suicide could be permissible under certain conditions. Yet, it would not be correct to consider Gandhi a proponent of euthanasia and assisted suicide, or to think that his arguments can be quoted in defence of these practices in the present. Gandhi's demand that first all care and nursing options should be tried before euthanasia or assisted suicide can be considered and his conviction that these efforts would hardly ever fail to bring sufficient relief make him in some sense an early advocate of palliative care in India.

\section{Funding}

The author has received funds as a Postdoctoral Research Fellow from the Fund for Scientific Research-Flanders (FWO). The FWO did not have any role in the study design, interpretation of the data, writing of the article, and the decision to submit the paper for publication. Grant Number 1.1.563.07.N.00.

\section{Bibliography}

1. Indian workers begin satyagraha: hope to confront Ronen Sen in D.C. on March 26. Hindustan Times (New Delhi) 2008;March 19:10.

2. Broeckaert B. Treatment decisions at the end of life: a conceptual framework. In: Payne S, Seymour J, Ingleton C, eds. Palliative care nursing: principles and evidence for practice. second ed. Birkshire: Open University Press 2008:402-21.

3. Broeckaert B. Euthanasia and physician assisted suicide. In: Walsh D, ed. Palliative Medicine. Philadelphia: Elsevier 2009:110-5. 
4. Broeckaert B, Flemish Palliative Care Federation. End of life decisions - A conceptual framework. http://www.palliatief.be/. 2006. Accessed 13 January 2012.

5. Crawford SC. Dilemmas of life and death: Hindu ethics in a North American context. Albany: State University of New York Press, 1995.

6. Crawford SC. Hindu bioethics for the twenty-first century. Albany: State University of New York Press, 2003.

7. Young K. Euthanasia: traditional Hindu views and the contemporary debate. In: Coward H, Lippner J, Young K, eds. Hindu ethics: purity, abortion and euthanasia. New York: State University of New York Press 1997.

8. Firth S. End-of-life: a Hindu View. Lancet 2005;366(9486):682-6.

9. Gandhi M. The collected works of Mahatma Gandhi. Delhi: Government of India, Ministry of Information and Broadcasting, Publications Division, 1958-1994.

10. Gandhi M. Selections from Gandhi, Bose NK ed. Ahmedabad: Navajivan Publishing House, 1948.

11. Materstvedt LJ, Clark D, Ellershaw J, et al. Euthanasia and physician-assisted suicide: a view from an EAPC ethics task force. Palliat Med 2003;17(2):97-101; discussion 102-79.

12. Clark D. Originating a movement: Cicely Saunders and the development of St Christopher's Hospice, 1957-1967. Mortality 1998;3(1):43-63.

13. Clark D. History, gender and culture in the rise of palliative care. In: Payne S, Seymour J, Ingleton C, eds. Palliative care nursing: principles and evidence for practice. Berkshire: Open University Press 2004:39-54.

14. Rajagopal MR, Palat G. Kerala, India: status of cancer pain relief and palliative care. J Pain Symptom Manage 2002;24(2):191-3.

15. Indian Association of Palliative Care. Palliative Care Centres. http://www.palliativecare.in/Palliative_Care_Centres.php. Accessed 6 January 2012.

16. Shanmugasundaram S, Chapman Y, O'Connor M. Development of palliative care in India: an overview. Int J Nurs Pract 2006;12(4):241-6.

17. International Observatory on End of Life Care. India Country Report. http://www.eolcobservatory.net/global_analysis/pdf/india_country_report.pdf. Accessed 13 January 2012.

18. McDermott E, Selman L, Wright M, et al. Hospice and palliative care development in India: a multi-method review of services and experiences. J Pain Symptom Manage 2008;35(6):583-593.

19. Seamark D, Ajithakumari K, Burn G, et al. Palliative care in India. $J$ R Soc Med 2000;93(6):292-5. 